\title{
Article \\ Effectiveness of Eggshells as Natural Heterogeneous Catalysts for Transesterification of Rapeseed Oil with Methanol
}

\author{
Ieva Gaide, Violeta Makareviciene *(D) and Egle Sendzikiene (D)
}

check for

updates

Citation: Gaide, I.; Makareviciene, V.;

Sendzikiene, E. Effectiveness of Eggshells as Natural Heterogeneous Catalysts for Transesterification of Rapeseed Oil with Methanol. Catalysts 2022, 12, 246. https:// doi.org/10.3390/catal12030246

Academic Editors: Hwai Chyuan Ong, Chia-Hung Su and Hoang Chinh Nguyen

Received: 10 February 2022 Accepted: 16 February 2022 Published: 22 February 2022

Publisher's Note: MDPI stays neutral with regard to jurisdictional claims in published maps and institutional affiliations.

Copyright: () 2022 by the authors Licensee MDPI, Basel, Switzerland. This article is an open access article distributed under the terms and conditions of the Creative Commons Attribution (CC BY) license (https:// creativecommons.org/licenses/by/ $4.0 /)$.

\author{
Agriculture Academy, Vytautas Magnus University, K. Donelaicio Str. 58, LT-44248 Kaunas, Lithuania; \\ ieva.gaide@vdu.lt (I.G.); egle.sendzikiene@vdu.lt (E.S.) \\ * Correspondence: violeta.makareviciene@vdu.lt
}

\begin{abstract}
Heterogeneous catalysis has an advantage of easy separation of the catalyst after biodiesel is produced. $\mathrm{CaO}$ is known to be an efficient heterogeneous catalyst for biodiesel production. Taking into account that $\mathrm{CaO}$ is a key component of eggshells, the effectiveness of eggshells as a heterogeneous catalyst for rapeseed oil transesterification with methanol was investigated and optimal conditions of biodiesel production were determined applying RSM methodology. The influence of three independent variables on ester content was analyzed and a quadratic model was created. It was determined that this model is statistically significant. The optimum transesterification conditions when eggshells are used as a heterogeneous catalyst, and the process temperature of $64{ }^{\circ} \mathrm{C}$, were determined as: the methanol-to-oil molar ratio 10.93:1; the catalyst amount $6.80 \mathrm{wt} \%$; the reaction duration $9.48 \mathrm{~h}$. The ester yield of $97.79 \mathrm{wt} \%$ was obtained under these conditions.
\end{abstract}

Keywords: transesterification; heterogeneous catalysis; eggshells; optimal conditions

\section{Introduction}

Increasing environmental pollution is caused by various factors, including the usage of vehicles. Legislation is being promoted to increase the use of renewable energy sources for fuel production. The use of electric cars is also being promoted, however, these are fairly new and expensive methods of transport. It is expedient to increase the amount of renewable energy in diesel fuel production, as $31.6 \%$ of all new cars registered in the European Union are powered by diesel engines in 2019 [1]. Also, most agricultural machinery is powered by diesel fuel [2], as are water vehicles such as, for example, boats [3], and therefore research on biodiesel production is relevant.

Biodiesel is usually produced in a homogeneous manner using chemical catalysts, for example, base catalysts $\mathrm{NaOH}, \mathrm{KOH}$, or acid catalysts $\mathrm{H}_{2} \mathrm{SO}_{4}$ [4]. Homogeneous catalysts can be used only once, so it is important to use heterogeneous catalysts that can be reused. $\mathrm{CaO}$ is known to be an efficient catalyst for biodiesel production [5], and research results show that $\mathrm{CaO}$ can be used as neat $\mathrm{CaO}$, doped $\mathrm{CaO}$, loaded $\mathrm{CaO}$, and mixed with metal oxides [6].

$\mathrm{CaO}$ is a key component of eggshells. The amount of worldwide egg production increased more than 14\% during the past decade and reached 76.7 million tons in 2018 [7]. Eggshell forms around 10\% of a chicken's egg by weight [8]. Experts from the European Commission predict that the production and consumption of eggs will increase over the next few years. It is predicted that egg consumption per capita is likely to increase to $15.0 \mathrm{~kg}$ (14.2 kg in 2021) and production is expected to increase to 6.77 million tons (with an average annual growth rate of $0.7 \%$ ) by 2030 [9]. As egg consumption increases, quantities of eggshells increase too.

The Circular Economy Action Plan is one of the key instruments of the new European Green Deal in the European Union. European Green Deal should lead to a climate-neutral, competitive, empowered consumer economy. The European Parliament wants Europeans 
to move towards a circular economy through the more efficient use of raw materials and by reducing amount of waste, which is of vital importance. The focus will be on waste prevention and the recycling of waste into high-quality secondary raw materials, for which a well-functioning secondary raw materials market will be important [10]. As it is not possible to reduce the amount of eggshells, it is important to try to use them. Currently most of the eggshells are treated as waste and are disposed in landfills with no or minimal pre-treatment [11]. Eggshell waste can be used as calcium supplement in animal feed [12], and as calcium absorption is better when it is natural in origin, eggshells are a good calcium source for use in pharmaceutical industries [13]. Calcium is important for living organisms, and for this reason eggshells can be used as a soil amendment [14] or even for human consumption [15].

Given the composition of eggshells, it can be argued that they could be used as a cheap heterogeneous catalyst in biodiesel synthesis. The aim of our work is to evaluate the catalytic efficiency of eggshells and to determine the optimal transesterification conditions to obtain biodiesel that meets the requirements of standards for biodiesel fuel.

\section{Results and Discussion}

\subsection{Eggshells Preparation}

It was found that chicken eggshells, which were used as a heterogeneous catalyst, contain $49.89 \pm 0.56 \%$ of $\mathrm{CaO}$, meaning $34.92 \%$ of their content is $\mathrm{Ca}$. Similar results were determined by Bartter et al., who reported that chicken eggshell is $38 \%$ calcium [14]. Brun et al. estimated the average calcium content in eggshells is $37.8 \%$ [15].

Catalyst preparation before using it for transesterification reaction is very important. Gaide et al. investigated dolomite as a heterogeneous catalyst for oil transesterification [16]. They determined that the optimum size of dolomite fraction was $0.315-0.1 \mathrm{~mm}$ and optimum calcination conditions are $4 \mathrm{~h}$ at $850^{\circ} \mathrm{C}$. For this research eggshells were prepared under the same conditions. Other researchers determined nearly similar optimum calcination temperature. Ramesh et al. stated that partial decomposition of $\mathrm{CaCO}_{3}$ to $\mathrm{CaO}$ was observed at $800{ }^{\circ} \mathrm{C}$ and higher temperatures [17]. This investigation showed that the most active eggshell sample was obtained when it was calcinated above $800{ }^{\circ} \mathrm{C}$. Using this sample as heterogeneous catalyst, an ester yield of $97-99 \%$ was obtained. Eggshells were used for the transesterification reactions before it was calcinated at $1000{ }^{\circ} \mathrm{C}$ for $2 \mathrm{~h}$ [18]. Other researchers determined that optimum calcination conditions for chicken eggshells were $900{ }^{\circ} \mathrm{C}$ in a muffle furnace for $3 \mathrm{~h}$ [19]. Granados et al. also determined an optimum calcination temperature of $900{ }^{\circ} \mathrm{C}$ [20].

\subsection{Modeling and Determination of Optimal Reaction Conditions Using Response Surface Methodology}

Most researchers determined that the optimum transesterification process temperature depends on the alcohol type. As a higher temperature intensifies the activity of the catalyst and the molecules move faster, this leads to a higher rate of collisions, and a higher temperature is desirable for transesterification reaction [19,21]. Most transesterification studies have been performed at the boiling point of alcohol, which depends on the type of alcohol used. The application of a higher boiling point than the alcohol requires additional measures to ensure that the alcohol does not evaporate from the reaction mixture and that the transesterification process is efficient. Therefore all our experiments were conducted under the $64^{\circ} \mathrm{C}$ as methanol's boiling point under the atmospheric pressure is $64.7^{\circ} \mathrm{C}$. The optimal temperature of $65{ }^{\circ} \mathrm{C}$ was reported by Wei et al. by investigating soybean oil transesterification using methanol and calcinated eggshells as heterogeneous catalyst [18].

Table 1 represents experimental design planned with ANOVA, the predicted responses and experimental values. The highest predicted ester yield was $98.95 \%$, when the methanolto-oil molar ratio was 10:1, the catalyst amount $7 \mathrm{wt} \%$ and the duration of the reaction was $11.2 \mathrm{~h}$. However, a very similar ester yield (98.66 $\mathrm{wt} \%$ ) was predicted when methanol-to-oil molar ratio was 10:1, catalyst amount $11.2 \mathrm{wt} \%$ and the duration of the reaction was $7 \mathrm{~h}$. 
The highest experimental ester yield obtained was $98.72 \pm 1.23 w t \%$ and $98.76 \pm 0.94 w t \%$, respectively.

Table 1. Experimental plan, predicted and experimental ester yield depending on independent variables.

\begin{tabular}{cccccc}
\hline No & $\begin{array}{c}\text { A: Methanol-to-Oil } \\
\text { Molar Ratio, } \\
\text { mol/mol }\end{array}$ & $\begin{array}{c}\text { B: Catalyst } \\
\text { Amount, } \\
\mathbf{w t} \%\end{array}$ & $\begin{array}{c}\text { C: Duration, } \\
\mathbf{h}\end{array}$ & $\begin{array}{c}\text { Predicted } \\
\text { Ester Yield, } \\
\mathbf{w t} \%\end{array}$ & $\begin{array}{c}\text { Experimental } \\
\text { Ester Yield, } \\
\mathbf{w t} \%\end{array}$ \\
\hline 1 & 4.00 & 4.00 & 4.00 & 3.19 & $11.44 \pm 0.89$ \\
2 & 16.00 & 4.00 & 4.00 & 2.32 & $8.12 \pm 0.66$ \\
3 & 4.00 & 10.00 & 4.00 & 60.05 & $65.97 \pm 0.69$ \\
4 & 16.00 & 10.00 & 4.00 & 12.83 & $15.50 \pm 0.34$ \\
5 & 4.00 & 4.00 & 10.00 & 25.41 & $32.51 \pm 0.46$ \\
6 & 16.00 & 4.00 & 10.00 & 71.66 & $75.26 \pm 0.29$ \\
7 & 4.00 & 10.00 & 10.00 & 95.93 & $99.50 \pm 0.67$ \\
8 & 16.00 & 10.00 & 10.00 & 95.83 & $97.28 \pm 0.36$ \\
9 & 1.60 & 7.00 & 7.00 & 38.28 & $25.17 \pm 0.46$ \\
10 & 18.40 & 7.00 & 7.00 & 37.61 & $32.36 \pm 0.56$ \\
11 & 10.00 & 2.80 & 7.00 & 47.95 & $35.87 \pm 0.87$ \\
12 & 10.00 & 11.20 & 7.00 & 98.66 & $98.72 \pm 1.23$ \\
13 & 10.00 & 7.00 & 2.80 & 32.00 & $20.34 \pm 0.65$ \\
14 & 10.00 & 7.00 & 11.20 & 98.95 & $98.76 \pm 0.94$ \\
15 & 10.00 & 7.00 & 7.00 & 89.53 & $92.45 \pm 0.75$ \\
16 & 10.00 & 7.00 & 7.00 & 89.53 & $89.56 \pm 0.69$ \\
17 & 10.00 & 7.00 & 7.00 & 89.53 & $92.56 \pm 0.47$ \\
18 & 10.00 & 7.00 & 7.00 & 89.53 & $90.78 \pm 0.34$ \\
19 & 10.00 & 7.00 & 7.00 & 89.53 & $91.89 \pm 0.67$ \\
20 & 10.00 & 7.00 & 7.00 & 89.53 & $91.34 \pm 0.63$ \\
\hline
\end{tabular}

The quadratic model showed an F value of 30.08 and a p value of less than 0.0001 and this indicates that the model is statistically significant (Table 2). Values less than 0.0500 are significant and therefore insignificant components were removed. Equation (2) describes the ester yield after the model was modified:

$$
E Y=86.27-0.24 A+20.26 B+26.31 C-11.59 A B+11.78 A C-26.95 A^{2}-11.20 C^{2}
$$

where:

EY-the ester yield (\%);

A-the methanol-to-oil molar ratio;

$\mathrm{B}$ - the catalyst amount (wt\%);

$\mathrm{C}$-the process duration (h).

The adjusted $R^{2}$ and predicted $R^{2}$ values are 0.9129 and 0.8597 , respectively, meaning that experimental values are in reasonable agreement with software predicted values and that the model can account for $91.29 \%$ of the response's variations. Adequate precision indicates the signal to noise ratio. Desirably, this ratio will exceed four. In this case, the value of adequate precision is 16.926 , which is more than four times higher the desirable number (Table 3).

A visual evaluation of the interaction of the independent variables that influence the ester yield can be observed in graphical images. Figure 1 shows the catalyst amount and methanol-to-oil molar ratio influence on ester yield when the process takes $7 \mathrm{~h}$. As we can see, a higher catalyst amount leads to the higher ester yield. The maximum ester yield cannot be reached when a small amount $(<4 \mathrm{wt} \%)$ of catalyst is used. As methanolto-oil molar ratio increases up to 13:1, the ester yield also increases. However, once the methanol-to-oil molar ratio moves above 13:1, the ester yield starts decreasing. 
Table 2. Analysis of the variance of the quadratic model.

\begin{tabular}{ccccccc}
\hline Source & $\begin{array}{c}\text { Sum of } \\
\text { Squares }\end{array}$ & df & $\begin{array}{c}\text { Mean } \\
\text { Square }\end{array}$ & F Value & $\begin{array}{c}p \text {-Value } \\
\text { Prob }>\text { F }\end{array}$ & \\
\hline $\begin{array}{c}\text { Model } \\
\text { A-butanol-to-oil }\end{array}$ & $23,650.36$ & 9 & 2627.82 & 30.08 & $<0.0001$ & Significant \\
molar ratio & 0.70 & 1 & 0.70 & $8.022 \times 10^{-3}$ & 0.9304 & \\
B-temperature & 4891.10 & 1 & 4891.10 & 56.00 & $<0.0001$ & \\
C-catalyst & 8249.05 & 1 & 8249.05 & 94.44 & $<0.0001$ & \\
AB & 1073.93 & 1 & 1073.93 & 12.29 & 0.0057 & \\
AC & 1110.38 & 1 & 1110.38 & 12.71 & 0.0051 & \\
BC & 93.23 & 1 & 93.23 & 1.07 & 0.3259 & \\
A2 & 5824.04 & 1 & 5824.04 & 66.68 & $<0.0001$ & \\
B2 & 382.59 & 1 & 382.59 & 4.38 & 0.0628 & \\
C2 & 938.00 & 1 & 938.00 & 10.74 & 0.0083 & \\
Residual & 873.48 & 10 & 87.35 & & & Not sig- \\
Lack of Fit & 871.48 & 5 & 174.30 & 435.74 & $<0.0001$ & nificant \\
Pure Error & 2.00 & 5 & 0.40 & 30.08 & & \\
Cor Total & $24,523.83$ & 19 & 2627.82 & & &
\end{tabular}

Table 3. Statistical parameters determined using ANOVA for the response surface model.

\begin{tabular}{cccc}
\hline Variable & Value & Variable & Value \\
\hline Std. Dev. & 10.60 & R-Squared & 0.9450 \\
Mean & 63.53 & Adj R-Squared & 0.9129 \\
C.V. $\%$ & 16.69 & Pred R-Squared & 0.8597 \\
PRESS & 3440.17 & Adeq Precision & 16.926 \\
\hline
\end{tabular}

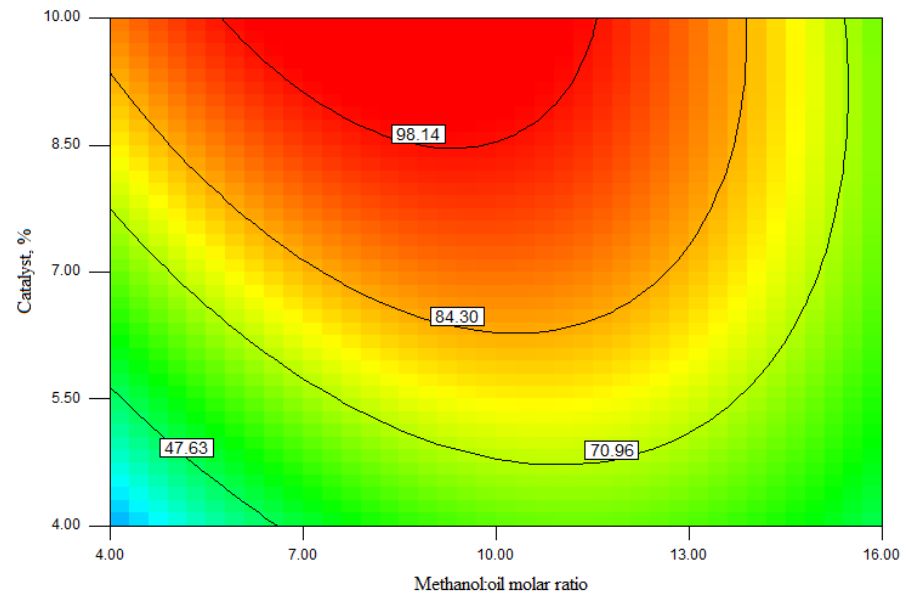

Figure 1. Response surface contour plot for the interaction between the catalyst amount and the methanol-to-oil molar ratio for the ester yield (the process duration is $7 \mathrm{~h}$ ).

Other researchers have observed the same tendency for the ester yield, which increases by increaseing the alcohol amount to a certain point. After that, the ester yield starts decreasing. Goli and Sahu [19] determined that the soybean methyl esters yield increases with an increase in the catalyst-chicken eggshells amount. The research found that ester yield increases with increasing methanol content, however a maximum amount of ester yield is obtained when the methanol-to-oil molar ratio is 10:1, and after that the ester yield starts decreasing [19]. Correia and colleagues obtained similar results investigating sunflower oil transesterification with methanol as a catalyst using quail eggshells. They determined that the optimum methanol and sunflower oil molar ratio is 10.5:1 and the maximum biodiesel production $99.00 \pm 0.02 \mathrm{wt} \%$ was obtained. It is not appropriate to 
increase the methanol content, as the reaction starts in the opposite direction, forming mono, di- and triglycerides and at the same time decreasing the yield of esters [22]. However, Kamaronzaman and colleagues have not observed such a trend, while transesterified waste cooking oil with methanol and chicken eggshells were used as a catalyst. During the research, the alcohol-to-oil molar ratio varied from 8:1 to 20:1 and the influence of the molar ration on the process effectiveness was investigated. It was determined that the optimum alcohol-to-oil molar ratio was 20:1, and the ester yield obtained was only $45.52 \mathrm{wt} \%$ [23]. A high optimum methanol-to-palm oil molar ratio (18:1) was obtained, however, the reaction duration was only $4 \mathrm{~min}$, under $900 \mathrm{~W}$ microwave power, and the ester yield was $96.7 \mathrm{wt} \%$ [24]. Wei and et al. (2009) determined that the optimum methanolto-soybean oil molar ratio was 9:1 (eggshells $6 \mathrm{wt} \%$ ). In this conditions $95 \%$ ester yield was reached [18]. These results are very similar to what was determined by our study.

The process duration and the methanol-to-oil molar ratio influence on the ester yield when the catalyst amount is $7 \mathrm{wt} \%$ is shown in Figure 2. The process duration influence on the transesterification reaction was tested, and the results show that the ester yield increases with time. When the methanol-to-oil molar ratio is higher than 10:1, a longer process duration is needed to reach the same ester yield $(>98 \mathrm{wt} \%)$. Similar trends were obtained in another study where the ester yield was investigated when the temperature was $57.5^{\circ} \mathrm{C}$ and catalyst amount was $7 \mathrm{wt} \%$. The maximum ester yield (93 $\mathrm{wt} \%$ ) was obtained when the methanol-to-oil molar ratio was 10:1 and the duration $3 \mathrm{~h}$, and increasing these parameter led to a decrease in the ester yield [19]. Many other researchers have obtained a high ester yield when the process takes $2-3 \mathrm{~h}[18,19,22,23]$, however, the ester yield obtained was less than $50 \mathrm{wt} \%$ after $4 \mathrm{~h}$ in our study.

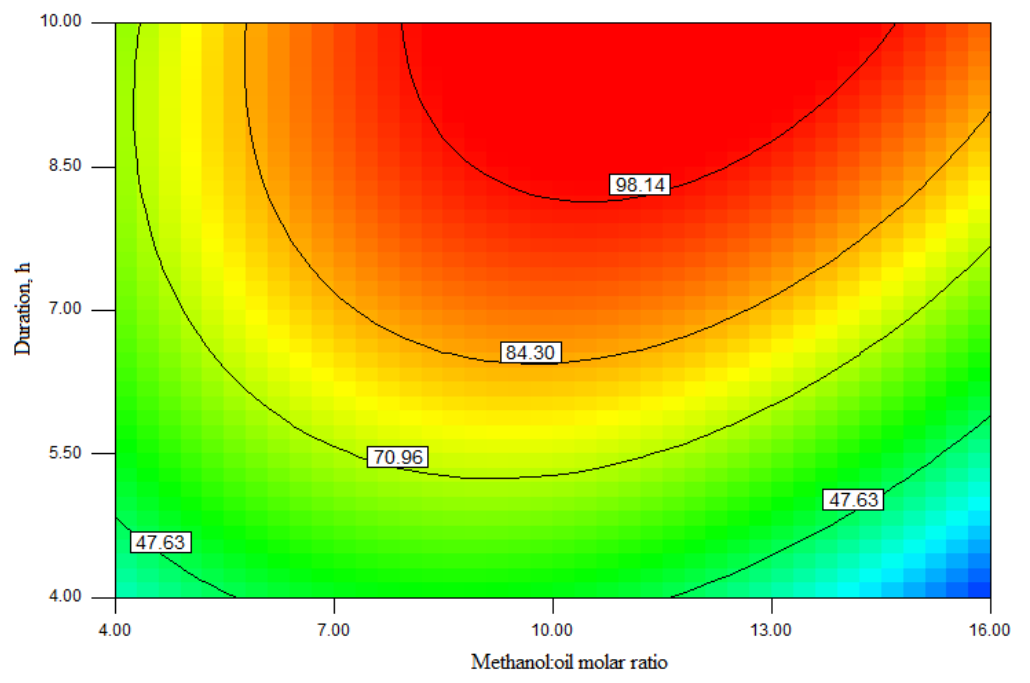

Figure 2. Response surface contour plot for the interaction between the process duration and the methanol-to-oil molar ratio for the ester yield (the catalyst amount is $7 \mathrm{wt} \%$ ).

Figure 3 demonstrates the impact of the process duration and the catalyst amount on the ester yield when the methanol-to-oil molar ratio is 10:1. As mentioned earlier, a longer process duration and higher catalyst amount have a positive influence on the ester yield. Goli et al. [19] analyzed eggshells as a heterogeneous catalyst for biodiesel synthesis as they investigated the influence of the catalyst amount and the process duration on the ester yield (process temperature $57.7^{\circ} \mathrm{C}$, methanol-to-oil molar ratio 10:1). It was observed that the ester yield increases to a certain point by increasing the process duration and the catalyst amount. An ester yield of $91.5-93 \mathrm{wt} \%$ was obtained when the process duration was $3 \mathrm{~h}$. By increasing the duration to $5 \mathrm{~h}$ and the catalyst amount to $12 \mathrm{wt} \%$, the ester yield decreased to $69.2 \mathrm{wt} \%$. Kumar et al. investigated waste cooking oil transesterification to biodiesel using eggshells and methanol and obtained that methanol-to-oil molar ratio has a positive influence on the biodiesel yield until a certain point, after which, the biodiesel yield starts 
to decrease [25]. This trend was not observed in our study. This can be explained by the process of ester hydrolysis and the consequent reduction in ester content.

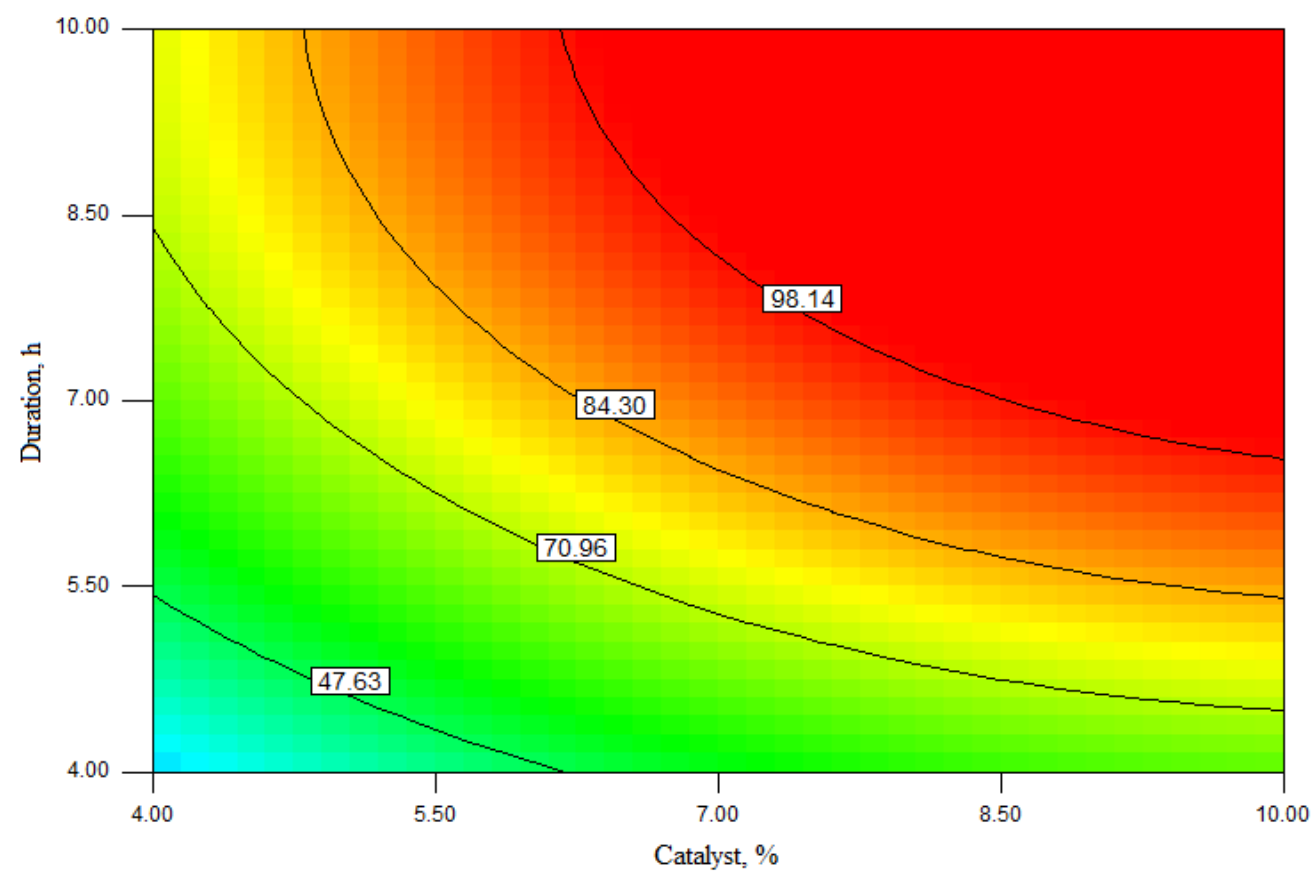

Figure 3. Response surface contour plot for the interaction between the process duration and the catalyst amount for the ester yield (the methanol-to-oil molar ratio is 10:1).

\subsection{Optimization of Rapeseed Oil Transesterification}

In this study, the influence of three independent variables on methyl esters' yield was investigated. It is important to determine optimum conditions for biodiesel production, therefore the methanol-to-oil molar ratio, the amount of the catalyst and the reaction duration were selected in a range and the ester yield was maximized. Optimization results are shown in Table 4, where predicted, and the experimental ester yield is also presented. Optimum conditions are the following: the methanol-to-oil molar ratio is 10.93:1; the catalyst amount is $6.80 \mathrm{wt} \%$ and the reaction takes $9.48 \mathrm{~h}$; temperature $64^{\circ} \mathrm{C}$. The highest predicted ester yield under these conditions is $98.95 \mathrm{wt} \%$. The experimental ester yield $(97.79 \mathrm{wt} \%)$ is very close to the predicted.

Table 4. Optimum parameters for biodiesel production, predicted and experimental ester yield.

\begin{tabular}{ccccc}
\hline $\begin{array}{c}\text { Methanol-to-Oil } \\
\text { Molar Ratio, } \\
\text { mol/mol }\end{array}$ & $\begin{array}{c}\text { Eggshells } \\
\text { Concentration, } \\
\text { wt\% }\end{array}$ & $\begin{array}{c}\text { Reaction } \\
\text { Duration, } h\end{array}$ & $\begin{array}{c}\text { Predicted } \\
\text { Ester } \\
\text { Yield, wt } \%\end{array}$ & $\begin{array}{c}\text { Experimental } \\
\text { Ester Yield, } \\
\text { wt\% }\end{array}$ \\
\hline $10.93: 1$ & 6.80 & 9.48 & 98.95 & $97.79 \pm 0.32$ \\
\hline
\end{tabular}

Other researchers investigated biodiesel production with methanol and eggshells, which were used as a heterogeneous catalyst. The optimum conditions of these studies are presented in Table 5. Studies were performed using different oils, and a methyl ester yield from 21 to $97.75 \mathrm{wt} \%$ was obtained. In our study the ester yield was even higher (97.79 wt \%). 
Table 5. A comparison of the optimum conditions for biodiesel production when eggshells are used as a heterogeneous catalyst.

\begin{tabular}{|c|c|c|c|c|c|c|}
\hline Oil & $\begin{array}{c}\text { Tempera } \\
{ }^{\circ} \mathrm{C}\end{array}$ & $\begin{array}{l}\text { Eggshells } \\
\text { Amount }\end{array}$ & $\begin{array}{c}\text { Reaction } \\
\text { Duration, } \\
\text { h }\end{array}$ & $\begin{array}{c}\text { Methanol-to-Oil } \\
\text { Molar Ratio, } \\
\text { mol/mol }\end{array}$ & $\begin{array}{c}\text { Ester Yield, } \\
\text { wt } \%\end{array}$ & Reference \\
\hline Sunflower & 60 & $2 w t \%$ & 2 & $10.5: 1$ & $99.00 \pm 0.02$ & [22] \\
\hline Sunflower & 60 & $3 w t \%$ & 3 & $9: 1$ & 97.75 & [27] \\
\hline Soybean & 65 & $3 w t \%$ & 3 & $9: 1$ & 95 & [18] \\
\hline Soybean & 25 & $5.8 w t^{\%} \%$ & 11 & $6: 1$ & 97 & [28] \\
\hline Soybean & 57.5 & $7 w \mathrm{t} \%$ & 3 & $10: 1$ & 93 & [19] \\
\hline Waste frying oil & 65 & $5 w t \%$ & 2 & $20: 1$ & 45.52 & [23] \\
\hline Waste frying oil & 65 & $5 w t \%$ & 1 & $12: 1$ & 94.52 & [26] \\
\hline Waste cooking & 50 & $5 \mathrm{~g}$ & 2 & $6: 1$ & 21 & [25] \\
\hline
\end{tabular}

The lowest ester yield ( $21 \mathrm{wt} \%)$ was obtained using waste cooking oil $\left(50^{\circ} \mathrm{C}, 5 \mathrm{~g}\right.$ of eggshells, 2 h, 6:1) [25]. Kamaronzaman, et al. transesterified waste cooking oil and obtained $45.5 \mathrm{wt} \%$ of methyl ester yield, with a methanol-to-oil molar ratio 20:1, catalyst amount $5 \mathrm{wt} \%$ and reaction duration $2 \mathrm{~h}$, and temperature $65^{\circ} \mathrm{C}$ [23]. Niju and colleagues obtained $94.52 \mathrm{wt} \%$ of the ester yield when waste frying oil was transesterified with methanol (methanol-to-oil molar ratio 12:1, reaction temperature $65^{\circ} \mathrm{C}$, eggshells amount $5 \mathrm{wt} \%$, reaction duration $1 \mathrm{~h}$ ) [26]. Even using the same oils-waste cooking oil, alcohol and catalyst-gave very different results that were difficult to explain. Both Kamaronzaman, et al. and Niju et al. investigated the transesterification process when all parameters, except the methanol-to-oil molar ratio, were the same, and the ester yield differed more than two times.

With sunflower oil at $60^{\circ} \mathrm{C}$, with $3 \mathrm{wt} \%$ of catalyst, a methanol-to-oil molar ratio of 9:1 and the duration $3 \mathrm{~h}$, a $97.75 \mathrm{wt} \%$ ester yield was obtained [27]. Very similar results were obtained by other researchers who investigated (reaction temperature $60{ }^{\circ} \mathrm{C}, 2 \mathrm{wt} \%$ of the catalyst, methanol-to-oil molar ratio 10.5:1, reaction duration 2 h) [22].

When soybean oil was used for transesterification, the ester yield ranged from 93 to $96 \mathrm{wt} \%$, depending on the conditions under which the processes were conducted. Piker et al. (2016) obtained $97 \mathrm{wt} \%$ ester yield under room temperature, however, the reaction duration was $11 \mathrm{~h}$ [28]. Other researchers obtained $93-95 \mathrm{wt} \%$ ester yield after $3 \mathrm{~h}$, with the temperature close to methanol's boiling point $[18,19]$. Our research was conducted under a temperature close to methanol's boiling point and the high ester yield was obtained (97.79 wt\%).

Rapeseed oil was used in our study, however, other researchers have not tested this kind of oil for the transesterification process. In this research, the optimum methanol-to-oil molar ratio was 10.93:1, which is similar to other researches: the optimum alcohol-to-oil molar ratio for the transesterification of sunflower oil was 10.5:1 [22] and 9:1 [27], for soybean oil transesterification that varied over a wider range from 6:1 to 10:1 $[18,19,28]$. The optimum catalyst amount in our study was $6.8 \mathrm{wt} \%$, in other studies it varied from 2 to $7 \mathrm{wt} \%$. The optimum process duration in this study was $9.48 \mathrm{~h}$, and many other researchers obtained a high ester yield over a shorter time; $1-3 \mathrm{~h}[18,19,22,23,25-27]$, Piker et al. determined $11 \mathrm{~h}$ as optimum process duration, however, the process was conducted at room temperature [28].

\subsection{Physical and Chemical Properties of Produced Biodiesel}

In order to determine whether the produced biodiesel can be used in the transport sector, the physical and chemical properties were investigated and compliance with the requirements of the standard LST EN 14214 was assessed. These are presented in Table 6. 
Table 6. The physical and chemical properties of rapeseed oil methyl esters.

\begin{tabular}{|c|c|c|c|}
\hline Parameter & Units & $\begin{array}{c}\text { EN } 14214 \\
\text { Requirements }\end{array}$ & $\begin{array}{l}\text { Rapeseed Oil } \\
\text { Methyl Esters }\end{array}$ \\
\hline Ester content & $\%$ & $\min 96.5$ & $97.79 \pm 0.32$ \\
\hline Density at $15^{\circ} \mathrm{C}$ & $\mathrm{kg} \mathrm{m}^{-3}$ & $\begin{array}{l}\min 860 \\
\max 900\end{array}$ & $885 \pm 0.24$ \\
\hline Viscosity at $40^{\circ} \mathrm{C}$ & $\mathrm{mm}^{2} \mathrm{~s}^{-1}$ & $\begin{array}{l}\min 3.50 \\
\max 5.00\end{array}$ & $4.83 \pm 0.02$ \\
\hline Acid value & $\mathrm{mg} \mathrm{KOHg}-1$ & $\max 0.5$ & $0.39 \pm 0.002$ \\
\hline Sulfur content & $\mathrm{mg} \mathrm{kg}^{-1}$ & $\max 10$ & $7.2 \pm 0.05$ \\
\hline Moisture content & $\mathrm{mg} \mathrm{kg}^{-1}$ & $\max 500$ & $228 \pm 0.34$ \\
\hline Iodine value & $\mathrm{g} \mathrm{J}_{2} 100^{-1} \mathrm{~g}^{-1}$ & $\max 120$ & $117 \pm 0.18$ \\
\hline $\begin{array}{l}\text { Linolenic acid methyl esters } \\
\text { content }\end{array}$ & $\%$ & $\max 12.0$ & $9.5 \pm 0.07$ \\
\hline Monoglyceride content & $\%$ & $\max 0.8$ & $0.47 \pm 0.04$ \\
\hline Diglyceride content & $\%$ & $\max 0.2$ & $0.09 \pm 0.01$ \\
\hline Triglyceride content & $\%$ & $\max 0.2$ & $0.04 \pm 0$ \\
\hline Free glycerol content & $\%$ & $\max 0.2$ & $0.02 \pm 0$ \\
\hline Total glycerol content & $\%$ & $\max 0.25$ & $0.22 \pm 0.15$ \\
\hline Methanol content & $\%$ & $\max 0.2$ & $0.08 \pm 0.001$ \\
\hline Phosphorus content, ppm & & 10 & $8 \pm 0.05$ \\
\hline Oxidation stability $110^{\circ} \mathrm{C}$ & $\mathrm{h}$ & $\min 8$ & $8.3 \pm 0.1$ \\
\hline Cetane number & - & $\min 51$ & $53.8 \pm 0.15$ \\
\hline Cold filter plugging point & ${ }^{\circ} \mathrm{C}$ & $\begin{array}{l}-5^{\circ} \mathrm{C} \text { (in summer) } \\
-32{ }^{\circ} \mathrm{C} \text { (in winter) }\end{array}$ & $-10 \pm 0.05$ \\
\hline
\end{tabular}

The main indicator of biodiesel quality is the ester yield. It shows the degree to which the transesterification reaction took place and how many fatty acid methyl esters were formed from the oil. According to EN 14214, biodiesel must contain at least $96.5 \%$ fatty acid methyl esters. The amount of biodiesel ester produced was found to meet the required standards and was $97.79 \pm 0.32 \mathrm{wt} \%$.

The purity of the biodiesel is defined by the content of free glycerol, mono-, di- and triglycerides and the total glycerol content of biodiesel. These parameters depend on the production method and the method of cleaning and purification of the final product. The content of free glycerol in biodiesel shall not exceed $0.02 \%(\mathrm{wt} / \mathrm{wt})$. If it is higher, it indicates that glycerol was not separated efficiently enough during purification and washing. The content of mono-, di- and triglycerides and the content of total glycerol in biodiesel is also very important. It must be less than $0.8 \%, 0.2 \%, 0.2 \%$ and $0.25 \%$ (wt/wt), respectively. Low concentrations of mono-, di- and triglycerides are obtained only if optimal process conditions are met or biodiesel is distilled. If the values in the final product are above the limit values, the use of such biofuels may result in sedimentation at the bottom of the fuel tank, interaction with other compounds and damage to the engine injection system or corrosion of metal alloys. The content of free glycerol, mono-, di- and triglycerides and total glycerol in the produced biodiesel meets the requirements of the standard.

Excess methanol is used in the production of biodiesel to transesterify oils or fats. The unreacted methanol is evaporated and washed with water, at the end of the process. In the case of quality biodiesel, the methanol content shall not exceed $0.2 \%(w t / w t)$. Higher amounts of methanol can pose a risk during transport and storage of fuels due to its relatively low flash-point and ignition temperatures. The methanol content of the produced biodiesel is only $0.08-0.001 \%$.

The iodine value indicates the degree of saturation of the fatty acids and is expressed in grams of iodine, which reacts with $100 \mathrm{~g}$ of biodiesel $\left(\mathrm{g} \mathrm{J}_{2} 100^{-1} \mathrm{~g}^{-1}\right)$. The maximum iodine value allowed is $120 \mathrm{~g} \mathrm{~J}_{2} 100^{-1} \mathrm{~g}^{-1}$. In addition to this indicator, the degree of unsaturation of the fatty acids in biodiesel is limited by the content of linolenic acid methyl ester, which must not exceed $12 \%$, and the content of polyunsaturated ( $\geq 4$ double bonds) methyl esters, which must not exceed $1 \%$. Biodiesel, which is characterized by a high content of mono- 
and polyunsaturated fatty acids, has been found to tend to polymerize and form deposits on the nozzles and piston rings. In addition, unsaturated esters with engine lubricants form high molecular weight compounds that degrade lubricating properties. The iodine value also correlates with other properties of biodiesel, such as viscosity and cetane number, both of which decrease with an increasing degree of unsaturation. As rapeseed oil is used in the production of biodiesel, which does not contain high amounts of mono- and polyunsaturated fatty acids, the resulting fuel meets the requirements of the standard.

The acid value indicates the content of mineral and free fatty acids in the biodiesel and is expressed in milligrams of potassium or sodium hydroxide required to neutralize the acids contained in $1 \mathrm{~g}$ of fatty acid methyl esters. The maximum limit for the acid value given in the European standard is $0.5 \mathrm{mg} \mathrm{KOHg}^{-1}$. The number of acids depends on the feedstock used for the production of biodiesel and the production process, which was used, as free fatty acids are also formed during transesterification and storage. Using biodiesel with high acid content can cause corrosion and sedimentation in the engine. The acid value of the obtained fuel is $0.39 \pm 0.002 \mathrm{mg} \mathrm{KOHg}^{-1}$.

Biodiesel has a higher density than mineral diesel. According to the requirements of the standard, it must be in the range of $860-900 \mathrm{~kg} \mathrm{~m}^{-3}$ under a temperature of $15^{\circ} \mathrm{C}$, while the density of mineral diesel is $820-845 \mathrm{~kg} \mathrm{~m}^{-3}$. This difference in density affects the calorific value of the fuel and the amount of fuel, which enters the combustion chamber. The density depends on the nature of the biodiesel (the fatty acid composition of the raw material) and its purity. The density of produced biofuels is $885 \pm 0.24 \mathrm{~kg} \mathrm{~m}^{-3}$.

Sulfur-rich fuels have a negative impact not only on the environment, but also on the human body, and therefore the amount of sulfur in biodiesel, as in the mineral diesel, is limited and must not exceed $10 \mathrm{mg} \mathrm{kg}^{-1}$. Sulfur-rich fuels not only increase sulfur oxide emissions, but also cause shorter engine life, reduced catalytic converter efficiency and service life, and reduced lubricity and damage to the injection pump. Conventional biodiesel—rapeseed oil fatty acid methyl esters are essentially free of sulfur compounds, and very low levels of sulfur may be due to glucosinolates or other compounds in rapeseed oil. The sulfur content of the produced biodiesel is $7.2 \pm 0.05 \mathrm{mg} \mathrm{kg}^{-1}$.

High quality biodiesel should not contain more than $500 \mathrm{mg} \mathrm{kg}^{-1}$ of moisture. Water is formed in the biofuels during the production process and is removed by drying the product. Due to the hygroscopic nature of fatty acid methyl esters, they can also absorb water during storage. The amount of water is limited as it causes microbiological processes, the formation of sludge and sediment can clog fuel lines and filters. In addition, in the presence of water, hydrolysis processes of biodiesel take place and free fatty acids are formed, which can also clog the filters, and the corrosion of chromium and zinc parts occurs.

In addition to the mentioned physical and chemical parameters above, it is very important that the fuel is stable and retains the required properties during extended storage and transportation. This is especially important for biodiesel, as contact with atmospheric oxygen results in oxidation processes that form free fatty acids, peroxides, aldehydes, and polymers that degrade the fuel and make the fuel unusable. The EN 14214 standard includes an indicator of oxidation stability, with a limit of at least $8 \mathrm{~h}$ at $110^{\circ} \mathrm{C}$. Oxidation stability of $8.3 \mathrm{~h}$ was obtained for our fuel.

It is very important that both mineral fuels and biofuels are usable during cold periods. They must not crystallize or freeze at low temperatures. There are different requirements for the limit cold filter plugging point (CFPP) value depending on the climatic conditions. In (Arctic climate class 2), fuels with an CFPP not higher than minus $32{ }^{\circ} \mathrm{C}$ must be used during the winter $\mathrm{CFPP}$-not higher than minus $15^{\circ} \mathrm{C}$ (temperate zone class E), CFPP not higher than minus $5{ }^{\circ} \mathrm{C}$ (temperate zone $\mathrm{C}$ ). CFPP of our obtained biodiesel is minus $10 \pm 0.05{ }^{\circ} \mathrm{C}$.

We finally concluded that our produced fatty acid methyl esters, produced by applying heterogeneous catalysis, meet the requirements of EN 14214 for biodiesel. 


\section{Materials and Methods}

\subsection{Preparation of the Catalyst}

Eggshells are a natural source of calcium carbonate, which can be converted to calcium oxide. Eggshells were prepared according Gaide et al. who analyzed optimum conditions for dolomite preparation for oil transesterification [16]. First of all, eggshells were crushed and heated in a muffle furnace (AB UMEGA SNOL 8.2/1100) for $4 \mathrm{~h}$ at $850{ }^{\circ} \mathrm{C}$. After calcination, the material was sieved through a sieve and fraction of $0.315-0.1 \mathrm{~mm}$ was collected.

\subsection{Determination of $\mathrm{CaO}$ in Eggshells}

Eggshells were decomposed by using $2 \mathrm{~g}$ of eggshells and $20 \mathrm{~mL}$ of royal water (nitric acid:hydrochloric acid in a molar ratio 1:3). After that $25 \mathrm{~mL}$ of the solution was mixed with $50 \mathrm{~mL}$ of water, $10 \mathrm{~mL}$ of ammonia buffer solution and the dark blue chromogen indicator and was titrated using trilon B (EDTA). Color changes from raspberry to violet followed. The $\mathrm{CaO}$ content was calculated according Equation (2):

$$
\mathrm{CaO}=\frac{\mathrm{V}_{1} \times \mathrm{K} \times 0.0014 \times 250}{\mathrm{~m} \times 25} \times 100 \%
$$

where:

$\mathrm{V}_{1}$ - the amount of trilon $\mathrm{B}$ used for calcium titration, $\mathrm{mL}$;

$\mathrm{V}_{2}$ - the amount of trilon B used for the titration of calcium, $\mathrm{mL}$;

$\mathrm{m}$-mass of the sample, $\mathrm{g}$;

$\mathrm{K}$-trilon B correction factor.

\subsection{Transesterification of Rapeseed Oil}

Rapeseed oil, which met the national requirements for edible oil, was bought in a local supermarket. Conical flasks, reflux condensers and stirrers were used for transesterification reactions. After, the reaction mixture was filtered. After removal of the catalyst from the reaction mixture, it was allowed to settle glycerol phase, which was then removed with the use of a separation funnel. The biodiesel was washed with $\mathrm{H}_{3} \mathrm{PO}_{4}(5 \%)$, solution $(10 \%$ by volume of the reaction product), and twice with distilled water (10\% by volume of the mixture). The residual water was evaporated at $110^{\circ} \mathrm{C}$ using magnetic stirrer.

\subsection{Gas Chromatography}

The amount of glycerides was determined in order to find ester yield in the samples. Glycerol, monoglycerides, diglycerides, and triglycerides were analyzed using a gas chromatograph Perkin Elmer Clarus 500 (Boston, MA, USA) detector-FID, column-Restek MXT-Biodiesel TG $(0.15 \mathrm{~m}-0.32 \mathrm{~mm}-0.10 \mu \mathrm{m}))$ based on the requirements of standard EN 14105.

Ester yield was calculated according to Equation (3) [16]:

$$
\mathrm{C}=\frac{\sum \mathrm{A}-\mathrm{A}_{\mathrm{EI}}}{\mathrm{A}_{\mathrm{EI}}} \times \frac{\mathrm{W}_{\mathrm{EI}}}{\mathrm{W}} \times 100
$$

where

C-content of ester, \%;

$\sum \mathrm{A}$ - the total peak area from methyl ester in C6:0 to that in C24:1;

$\mathrm{A}_{\mathrm{EI}}$ - the peak area corresponding to nonadecanoic acid methyl ester;

$\mathrm{W}_{\mathrm{EI}}$ - the weight $(\mathrm{mg})$ of the nonadecanoic acid methyl ester being used as internal standard; $\mathrm{W}$-the weight $(\mathrm{mg})$ of the sample.

\subsection{Response Surface Analysis}

Response surface methodology (RSM) was used for setting the experimental plan and analysis of the results. For determination of the optimal conditions for the transesterification 
of rapeseed oil with methanol and eggshells as heterogeneous catalyst, Design Expert version 8.01 was used.

The yield of methyl esters was optimized depending on the amount of methanol and the catalyst and the reaction time using a reaction surface methodology based on actual experiments. The transesterification reaction was carried out in a laboratory reactor under different conditions, varying the values of the parameters listed above: the methanol-to-oil molar ratio (mol:mol) (from 4 to 16), the catalyst amount (from 4 to $10 \mathrm{wt} \%$ ), and the reaction duration (from 4 to $10 \mathrm{~h}$ ). Reaction conditions were varied by performing experiments according to an experimental design consisting of 24 points in the Box-Behnken experimental design and $2^{4-1}$ points in the fractional factor design [29]. The experimental plan consisted of 20 assays.

A mathematical model was created using a computer simulation program. A quadratic reaction surface model was used to determine the interaction between the transesterification reaction conditions and the fatty acid methyl esters yield.

As there were three factors involved in this research, the mathematical relationship between factors and the response is shown in Equation (4) [29]:

$$
Y=\beta_{0}+\beta_{1} x_{1}+\beta_{2} x_{2}+\beta_{3} x_{3}+\beta_{11} x_{1}^{2}+\beta_{22} x_{2}^{2}+\beta_{33} x_{3}^{2}+\beta_{12} x_{1} x_{2}+\beta_{13} x_{1} x_{3}+\beta_{23} x_{2} x_{3}
$$

where:

$\mathrm{Y}$-predicted response;

$\beta_{0}$-the offset term;

$\beta_{\mathrm{i}}$-the linear coefficients;

$\beta_{\mathrm{ii}}$ and $\beta_{\mathrm{ij}}$ - the interaction coefficients;

$x_{i}$ and $x_{j}$ - the independent variables

After all experiments were performed, the results were analyzed and a final model that best fitted was applied. The selected model gave the values of independent variables, from which the maximum ester yield can be obtained.

\subsection{Determination of Physical and Chemical Properties of Biodiesel}

The physical and chemical properties of produced biodiesel were analyzed according to the requirements of standard EN ISO 14214.

\section{Conclusions}

Eggshells are waste, which form around 10\% of a chicken's egg. Eggshells contain $49.98 \%$ of $\mathrm{CaO}$, and therefore, it is an effective heterogeneous catalyst for biodiesel production. Before using eggshells as a catalyst it has to be prepared-calcinated for $4 \mathrm{~h}$ at $850{ }^{\circ} \mathrm{C}$ and sieved in order to obtain $0.315-0.1 \mathrm{~mm}$ size fraction.

The influence of three independent variables (the methanol-to-oil molar ratio, the catalyst amount and the reaction duration) on the efficiency of the transesterification process was investigated. It was found that the higher catalyst amount and the longer process duration leads to a higher ester yield, however, increasing the methanol amount is useful to the certain point. The optimization of heterogeneous rapeseed oil transesterification with methanol was performed using response surface methodology. It was obtained that the optimum process conditions are the following: methanol-to-oil molar ratio 10.93:1; catalyst amount $6.80 \mathrm{wt} \%$ and the reaction duration of $9.48 \mathrm{~h}$ at $64{ }^{\circ} \mathrm{C}$. Ester yield at the determined optimal conditions was $97.79 \mathrm{wt} \%$. The produced biofuels meet the requirements of standard EN 14214 in terms of physical and chemical properties and can be used as fuel for diesel engines during the summer.

Author Contributions: Conceptualization, V.M. and E.S.; methodology, I.G., V.M. and E.S.; software, I.G.; validation, I.G., V.M. and E.S.; formal analysis, investigation, I.G. and V.M.; resources, E.S.; data curation, I.G. and V.M.; writing—original draft preparation, I.G., V.M. and E.S.; writing—review and 
editing, I.G., V.M. and E.S.; visualization, I.G. and E.S.; supervision, V.M. All authors have read and agreed to the published version of the manuscript.

Funding: This research received no external funding.

Data Availability Statement: The data presented in this study are available on request from the corresponding author.

Conflicts of Interest: The authors declare no conflict of interest.

\section{References}

1. ACEA. 2021. Available online: https://www.acea.auto/figure/fuel-types-of-new-passenger-cars-in-eu/ (accessed on 5 October 2021).

2. React Power Team. How Engines Evolved with The Agricultural Industry. 2019. Available online: https://www.reactpower. $\mathrm{com} / \mathrm{blog} /$ how-engines-evolved-with-the-agricultural-industry/ (accessed on 19 October 2021).

3. Chiche, A.; Andruetto, C.; Lagergren, C.; Lindbergh, G.; Stenius, I.; Peretti, L. Feasibility and impact of a Swedish fuel cell-powered rescue boat. Ocean Eng. 2021, 234, 109259. [CrossRef]

4. Vishal, D.; Dubey, S.; Goyal, R.; Dwivedi, G.; Baredar, P.; Chhabra, M. Optimization of alkali-catalyzed transesterification of rubber oil for biodiesel production \& its impact on engine performance. Renew. Energy 2020, 158, 167-180.

5. Anantapinitwatna, A.; Ngaosuwan, K.; Kiatkittipong, W.; Wongsawaeng, D.; Anantpinijwatna, A.; Quitain, A.T.; Assabumrungrat, S. Water influence on the kinetics of transesterification using CaO catalyst to produce biodiesel. Fuel 2021, 296, 120653. [CrossRef]

6. Marinković, D.M.; Stanković, M.V.; Veličković, A.V.; Avramović, J.M.; Miladinović, M.R.; Stamenković, O.O.; Veljković, V.B.; Jovanović, D.M. Calcium oxide as a promising heterogeneous catalyst for biodiesel production: Current state and perspectives. Renew. Sustain. Energy Rev. 2016, 56, 1387-1408. [CrossRef]

7. Shahbandeh, M. Egg Production: Leading Countries Worldwide 2018. Statista. 2020. Available online: https://www.statista. com/statistics/263971/top-10-countries-worldwide-in-egg-production/ (accessed on 26 October 2021).

8. Laca, A.; Laca, A.; Díaz, M. Eggshell waste as catalyst: A review. J. Environ. Manag. 2017, 197, 351-359. [CrossRef]

9. Available online: https://www.hartmann-packaging.com/world/think-news/2-2021-european-egg-market/ (accessed on 15 November 2021).

10. Available online: https://ec.europa.eu/commission/presscorner/detail/en/ip_20_420 (accessed on 23 September 2020).

11. Gao, Y.; Xu, C. Synthesis of dimethyl carbonate over waste eggshell catalyst. Catal. Today 2012, 190, 107-111. [CrossRef]

12. Quina, M.J.; Soares, M.A.R.; Quinta-Ferreira, R. Applications of industrial eggshell as a valuable anthropogenic resource. Resour. Conserv. Recycl. 2017, 123, 176-186. [CrossRef]

13. Aditya, S.; Stephen, J.; Radhakrishnan, M. Utilization of eggshell waste in calcium-fortified foods and other industrial applications: A review. Trends Food Sci. Technol. 2021, 115, 422-432. [CrossRef]

14. Bartter, J.; Diffey, H.; Yeung, Y.H.; O’Leary, F.; Häsler, B.; Maulaga, W.; Alders, R. Use of chicken eggshell to improve dietary calcium intake in rural sub-Saharan Africa. Matern. Child Nutr. 2018, 3, e12649. [CrossRef]

15. Brun, L.R.; Lupo, M.; Delorenzi, D.A.; Di Loreto, V.E.; Rigalli, A. Chicken eggshell as suitable calcium source at home. Int. J. Food Sci. Nutr. 2013, 64, 740-743. [CrossRef]

16. Gaide, I.; Makareviciene, V.; Sendzikiene, E.; Kazancev, K. Natural Rocks-Heterogeneous Catalysts for Oil Transesterification in Biodiesel Synthesis. Catalysts 2021, 11, 384. [CrossRef]

17. Ramesh, S.; Natasha, A.N.; Tan, C.Y.; Bang, L.T.; Ramesh, S.; Ching, C.Y.; Thambinayagam, C.H. Direct conversion of eggshell to hydroxyapatite ceramic by a sintering method. Ceram. Int. 2016, 42, 7824-7829. [CrossRef]

18. Wei, Z.; Xu, C. Application of waste eggshell as low-cost solid catalyst for biodiesel production. Bioresour. Technol. 2009, 100, 2883-2885. [CrossRef] [PubMed]

19. Goli, J.; Sahu, O. Development of heterogeneous alkali catalyst fromwaste chicken eggshell for biodiesel production. Renew. Energy 2018, 128, 142-154. [CrossRef]

20. Granados, L.M.; Poves, Z.M.D.; Alonso, M.D.; Mariscal, R.; Galisteo, C.F.; Tost, M.R.; Santamaria, J.; Fierro, G.L.J. Biodiesel from sunflower oil by using activated calcium oxide. Appl. Catal. B Environ. 2007, 73, 317-326. [CrossRef]

21. Ahmad, S.; Chaudhary, S.; Pathak, V.V.; Kothari, R.; Tyagi, V.V. Optimization of direct transesterification of Chlorella pyrenoidosa catalyzed by waste egg shell based heterogenous nano-CaO catalyst. Renew. Energy 2020, 160, 86-97. [CrossRef]

22. Correia, L.M.; Cecilia, J.A.; Rodríguez-Castellón, E.; Cavalcante, C.L.; Vieira, R.S. Relevance of the Physicochemical Properties of Calcined Quail Eggshell (CaO) as a Catalyst for Biodiesel Production. J. Chem. 2017, 2017, 5679512.

23. Kamaronzaman, M.F.F.; Kahar, H.; Hassan, N.; Hanafi, M.F.; Sapawe, N. Optimization of biodiesel production from waste cooking oil using eggshell catalyst. Mater. Today Proc. 2020, 31, 324-328. [CrossRef]

24. Khemthong, P.; Luadthong, C.; Nualpaeng, W.; Changsuwan, P.; Tongprem, P.; Viriya-Empikul, N. Industrial eggshell wastes as the heterogeneous catalysts for microwave-assisted biodiesel production. Catal. Today 2010, 190, 112-126. [CrossRef]

25. Kumar, H.; Renita, A.A.; Anderson, A. Response surface optimization for biodiesel production from waste cooking oil utilizing eggshells as heterogeneous catalyst. Mater. Today Proc. 2021, 47, 1054-1058. [CrossRef] 
26. Niju, S.; Begum, M.S.; Anantharaman, N. Modification of egg shell and its application in biodiesel production. J. Saudi Chem. Soc. 2014, 18, 702-706. [CrossRef]

27. Correia, L.M.; Saboya, R.M.A.; de Susa Campelo, N.; Cecilia, J.A.; Rodrguez-Castelln, E.; Cavalcante, C.L.; Vieira, M.R.S. Characterization of calcium oxide catalysts from natural sources and their application in the transesterification of sunflower oil. Bioresour. Technol. 2014, 151, 207-213. [CrossRef] [PubMed]

28. Piker, A.; Tabah, B.; Perkas, N.; Gedanken, A. A green and low-cost room temperature biodiesel production method from waste oil using egg shells as catalyst. Fuel 2016, 182, 34-41. [CrossRef]

29. Montgomery, D. Design and Analysis of Experiments; John Wiley \& Sons: New York, NY, USA, 2001. 